Historic, archived document Do not assume content reflects current
scientific knowledge, policies, or practices. 



\section{The Peony}

To make more real our slogan-"EVERYTHING THAT IS GOOD AND HARDY"-we have purchased the entire stock of Peonies from that lifelong enthusiast and specialist, Mr. E. A. Reeves, of Chagrin Falls, Ohio.

This stock of 100,000 plants includes the Gold Medal Collection with which he took many prizes.

As we have to move this stock to our nursery this Fall, we are making very special prices to dispose of our surplus.

If June had done nothing but give us roses it would have been enough to have immortalized it as the Flower Month. But Nature is lavish of her gifts to the limit of prodigality. It would take more than a page to even mention the names of the flowers that bloom in June, and it is our purpose here to mention but one.

The Peony is a close rival of the rose, either for planting or for cutting. Its iron-clad hardiness, adaptability to varying soils and locations, its wealth of bloom, richness of fragrance, and variety of color, all go to make it a general favorite. So we find it in a single clump by the cottage door or in pleasing variety in the flower garden; in costly and rare varieties in the grounds of the collector, and in extensive plantings in parks and in the grounds of the wealthy.

The plant we send out is a strong, healthy, three- to five-eye plant, not the small two-to threeeye division often sold and which we believe is too small to give satisfaction. Our plants will often throw one or two good blooms the first season.

For more immediate effect we advise the fiveto nine-eye, three-year clump, or still better the ten- to fifteen-eye, four-year clump.

September and October are the best months in which to plant Peonies, although they are planted fairly satisfactorily in March or early April. In planting, cover the "eyes" with about two inches of soil and use a slight mulch. Too deep planting is the cause of many Peonies not blooming. Fertilize with bone-meal, wood ashes and sparingly with stable manure.

The figure on the margin is the rating given by the Peony Society, using ten (10) as a perfect Peony.

You will note that we are listing only about fifty of the best kinds, making a good concise list which we believe will fill all of your requirements. However, we have a great many other varieties and would be glad to quote you on any special variety you may want.

Prices are for three- to five-eye plants.

Five- to nine-eye, three-year clumps for twice the price.

Ten- to fifteen-eye, four-year clumps for three times the price.

Rating Variety

Each Per 10

8.8 Albatre (Crousse, 1885). Ivorywhite, very large, very double, central petals margined with carmine. One of the grandest white Peonies ............\$ \$0.90 \$8.00

8.0 Aurore (Dessert, 1904). Large, loose, lilac-white; center flecked with crimson; stamens conspicuous. A fine sort ........ 1.50

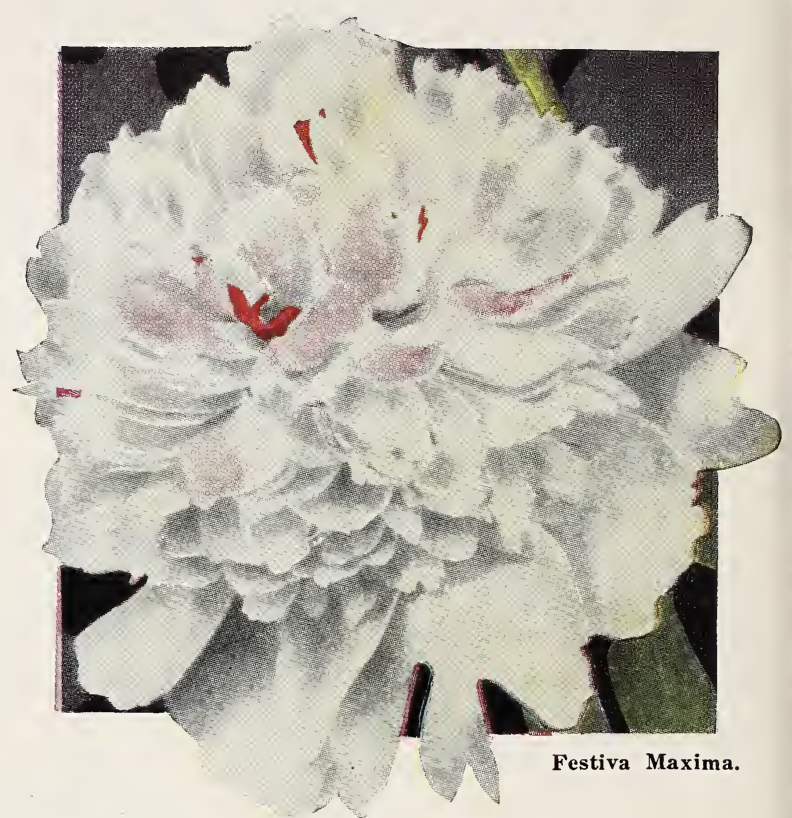

Rating

Variety

Each Per 10

9.0 Baroness Schroeder (Kelway).

Very large, flesh-white to milkwhite. Fragrant, strong, tall. grower and free bloomer. One of the finest pinks. Midseason. $\$ \$ 1.50 \quad \$ 12.00$

Belle Douaisienne (Calot, 1861). Large, hydrangea-pink, flecked with carmine. A very sweet and beautiful flower. Midseason ................. 1.00

Boadiceae (Unknown). Delicate white, touched with carmine. Strong grower, healthy foliage; medium late .............

8.0 Boule de Neige (Calot, 1862). White with sulphur center, inner petals margined with carmine. Dainty and beautiful.

8.7 Claire Dubois (Crousse, 1886). Very large, very double with tufted center. Very free bloomer. One of the finest Peonies we have $. . \ldots \ldots \ldots \ldots \ldots . . . .$.

Comte de Gomer (Calot, 1868). Very rich red. Very full and double. Late; extra fine ..... 1.00

8.1 Couronne d'Or (Calot, 1873). Very large, ball-shaped bloom. Snow-white with carmine edges and a ring of yellow stamens around the center petals. Strong grower and free bloomer. Grand.

7.1 Delachei (Delache, 1856). Deep purplish crimson; strong grower. Free bloomer and one of the very good dark red Peonies. Midseason to late ........... 
$\begin{array}{ll}\text { Rating } & \text { Variety } \\ \text { 7.6 Delicatissima (Unknown). Light }\end{array}$ pink; early. Large and fine. Free bloomer; fine for cut flowers $\ldots \ldots \ldots \ldots \ldots \ldots \ldots . \ldots 0.50 \$ 4.00$

7.7 Dorchester (Richardson). Late; light cream colored pink; very double; sweet and fine .......

7.6 Edulis Superba (Lemoine, 1824). Early, dark pink; free bloomer..

8.3 Eugene Bigot (Dessert, 1894). Dazzling Tyrian shade with silver tipped petals; rather late. Valued sort ............ 2.00

8.6 Eugenie Verdier (Calot, 1864). Salmon-pink fading to clear pink or white. Free bloomer. Midseason; fine ............. 1.00

8.4 Felix Crousse (Crousse, 1881). Large, ball-shaped, brilliant red, with ruby center. Very attractive and desirable. Late ......

8.0 Festiva (Donkalaer, 1838). Pure white, carmine touched in center; much like Festiva Maxima

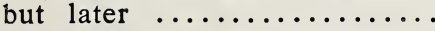

9.3 Festiva Maxima (Miellez, 1851). Very large, free bloomer; pure white with carmine touched center. Strong stems; early...

7.3 Golden Harvest (Rosenfield). Outer petals lilac-rose, center cream-white with pink. Strong, vigorous grower. Very free bloomer. Much like Jeanne d'Arc. A fine sort ...........

8.8 Grandiflora (Richardson, 1883). Rose-white, very fragrant; tall vigorous grower. One of the last to bloom. Very valuable sort ................... 1.25

Kelway's Queen (Kelway, 1909). Blush pink; a delicate and lovely sort; very sweet. Late. A rare sort. New .............. 10.00

8.5 La Perle (Crousse, 1885). Soft flesh pink, with a satiny border. Perfectly formed flower, very dainty, beautiful and desirable. 1.00
Rating

Variety

Each Per 10

7.5 La Tulipe (Calot, 1872). Very large, loose bloom, on strong, long stems. Delicate creamwhite. Center petals marked with carmine. Carmine marked guard petals. Late. A free bloomer and fine .........\$0.50 \$4.00

8.1 L'Etincelante (Dessert). Bright carmine with golden stamens at center. Very showy and beau-

tiful. Single ........... 2.00

7.3 L'Indispensable (Unknown). Lavender-white shading to rose at center. Buds slow to open. Tall, strong grower; early. A fine sort $\ldots \ldots \ldots \ldots \ldots \ldots \ldots$

6.9 Louis Van Houtte (Calot, 1867). Bright red. Free bloomer on strong, upright stems. Late ...

8.5 Maud L. Richardson (Hollis, 1904). Pale lilac-rose with lighter center. Fragrant; tall, strong grower; free bloomer and late $\ldots \ldots \ldots \ldots \ldots \ldots . . .4 .00$

8.3 Marie Jacquin (Verdier). Rosewhite fading to lilac-white; petals incurved. Conspicuous yellow stamens in center. Distinct and beautiful variety. Single ................ 1.00

7.4 Mme. Bollet (Calot, 1867). Clear rose, with light reflects striped with carmine. Strong grower; free bloomer. Very late .....

7.7 Mme. de Vatry (Guerin, 1863). Outer petals flesh color, center buff-white, with carmine stripes. Free bloomer; dwarf habit. Medium late ................

7.9 Mme. de Verneville (Crousse, 1885). Large blooms of creamwhite shading to blush in center, with a touch of carmine. Free bloomer. A grand sort ............

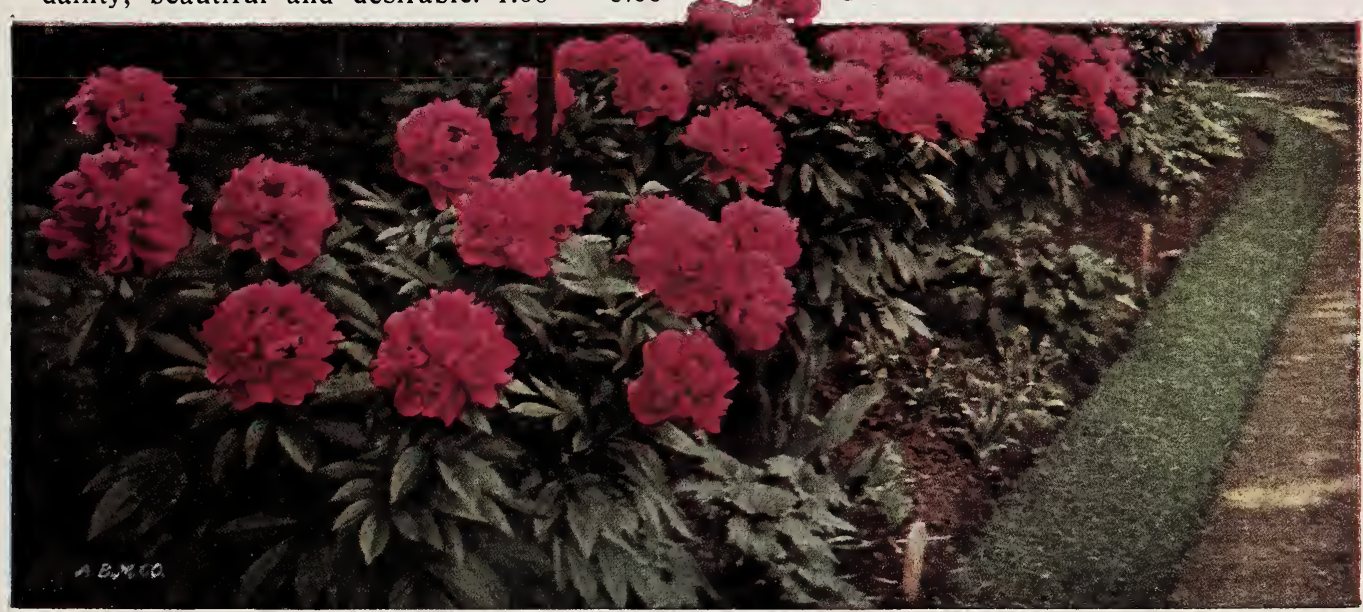

Edulis Superba. 
Rating
8.5 Mme. Emile Galle (Crousse 1881). Large lavender blooms shading lighter in the center. A very attractive and beautiful color. Free bloomer, and one of the finest ..........\$ $\$ 0.60$

8.9 Mme. Emile Lemoine (Lemoine, 1899). Large, milk-white bloom with touches of carmine on reflex petals. Free bloomer, upright habit; midseason; extra fine sort .............. 1.00

7.7 Mme. Forel (Crousse, 1881). Very large, globular, glossy pink blooms, borne on long, strong stems. Fine, upright habit; free bloomer. A splendid sort; late.

7.9 Mme. Geissler (Crousse, 1880). Very large, silvery rose; free bloomer; a grand and attractive flower ................ 1.00

7.5 Modeste Guerin (Guerin, 1845). Solferino-red. Fragrant; midseason. Medium height; strong stems; free bloomer. Extra fine

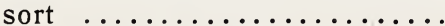

7.1 Mons. Boucharlataine (Calot, 1868). Very large, well shaped blooms on strong, erect stems; pure lavender-pink with carmine spots on center petals. Rather

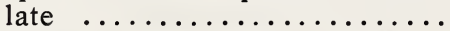

Officinalis Rubra Plena. The old double red Peony of our grandmother's garden. The earliest to bloom ..............
Rating

Variety

Each Per 10

7.4 Princess Beatrice (Kelway, 1886).

Large, very double flower, outer petals rose, collar cream-white. Center flecked with carmine. Vigorous grower, free bloomer; fragrant; early .............

6.8 Queen Victoria (Kelway, 1830). (Syn. Whitleyi). Large, compact bloom, with broad outer petals; opens blush-white, shading to pure white. Center petals marked red. Medium early; a fine cut flower sort ........

7.2 Rubra Superba (Richardson) Large double flowers borne on strong stems. Color bright crimson; fragrant. It does not show its merits until well established. By many considered the most beautiful Peony grown. Very

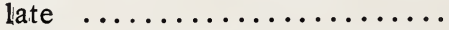

7.9 Simonne Chevalier (Dessert, 1902). Pale lavender-rose, collar cream-white. Fragrant; medium height. Early ..........

7.4 Souvenir de Gaspard Calot (Calot, 1865). Shell-pink with soft lilac. Large blooms; very double; upright habit. Very late..

7.6 Souvenir de L'Exposition Universelle (Calot, 1867). Bright cherry-red; very double. Mid-

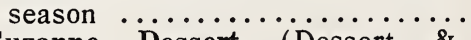

7.7 Suzanne Dessert (Dessert \& Mechin, 1890). Large, full flowers in clusters. Clear chinapink; very free bloomer; good habit; showy .............

9.8 Therese (Dessert, 1904). Light pink, shading to lilac-white in the center. Strong, erect; free bloomer. Midseason. One of the choicest sorts. Note the rating ............ 5.00

7.8 Triumph de L'Exposition de Lille (Calot, 1865). Light pink with white reflex. Very free bloomer; fine, upright habit; desirable .........

Umbellata Rosea (Unknown). Light shell-pink; upright habit; free bloomer. Fine for cutting. The earliest Chinese sort in our collection ...

7.6 Virginie (Calot, 1858). Lively pink; fine shaped bloom. Very free bloomer. Midseason $\ldots . . . . .$. .

Red $\ldots \ldots \ldots \ldots \ldots$

Pink or White ......

Mixed .......... .25

10 plants in 10 distinct varieties, our selection ............\$4.00 25 plants in 25 distinct varieties, our selection ............\$8.00

50 plants in 50 distinct varieties, our selection ...........\$16.00 


\section{Phlox}

Everyone knows this stately old plant, but few realize and know the beauty of the glorious colored newer varieties. The price always tells which are best and what is a few cents more when you will have the plant to look at for years.

Variety Each Per 10

Alceste. Violet shading to light blue. . $\$ 0.30$

Annie Cook. Flesh-pink ........ .20

Astrild. Carmine. Fine .......... .30

Athis. Salmon-pink ........... .20

Baur's Pink. Bright deep pink. An improved "Sunset" ............

B. Comte. Deep, rich, ox blood-red. Fine $. . . \ldots \ldots \ldots \ldots \ldots \ldots \ldots \ldots . . .35$

Bridesmaid. White, carmine eye ... .20

Crepuscle. Rose-lilac, tinged white. Extra .......................

Eclaireur. Brilliant rosy magenta, white eye..$\ldots \ldots \ldots \ldots \ldots \ldots$.

Elizabeth Campbell. Salmon-pink, dark crimson eye. Fine ........

Europa. White, crimson eye. Best of type $\ldots \ldots \ldots \ldots \ldots \ldots \ldots$.

Frau Anton Buchner. The best white.

Glow. A gorgeous colored Phlox. Salmon-red. New ............

Independence. Pure white. Old but

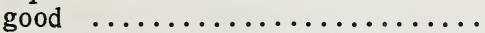

Jules Sandeau. Pure pink. Dwarf. Mammoth flowers ..............
$\$ 2.50$

1.50

2.50

1.50

.25

2.00

3.00

1.50

2.50

.25

.35

.30

.25

.40

.20

.30

3.00
Variety Each Per 10

La Vague. Clear, silvery rose $\ldots . \$ 0.20 \$ 1.50$

Mad. Bezanson. Scarlet ........ .25 2.00

Miss Lingard. Early, waxy white .. $\quad .25 \quad 2.00$

Mrs. Dwyer. White, pink eye. Large. $.25 \quad 2.00$

Mrs. Jenkins. White. The old standard ........................ 10

Pantheon. Soft rose-pink. Beautiful.. $.25 \quad 2.00$

Peach Blow. Delicate pink ....... .25 2.00

Pearl. White ................ .20 1.50

Percheau d'Island. Deep red; tall; good $\ldots \ldots \ldots \ldots \ldots \ldots \ldots \ldots . .25 \quad 2.00$

Professor Virchow. Bright carmine and orange-scarlet $\ldots \ldots \ldots \ldots \ldots . .30$

2.00 Rheinlander. Salmon-pink, claret eye. New. Fine .............. .25

2.50

R. P. Struthers. Carmine, red eye.. .25

2.00

Special French. Glowing pink. Mammoth trusses. We believe this to be the best landscape Phlox in existence ...................

Thor. Salmon-pink with crimson eye. New ..................30

1.50 Von Lassburg. Fine white ....... .20

Widar. Light reddish violet, white eye. Novelty $\ldots \ldots \ldots \ldots \ldots \ldots . .30$

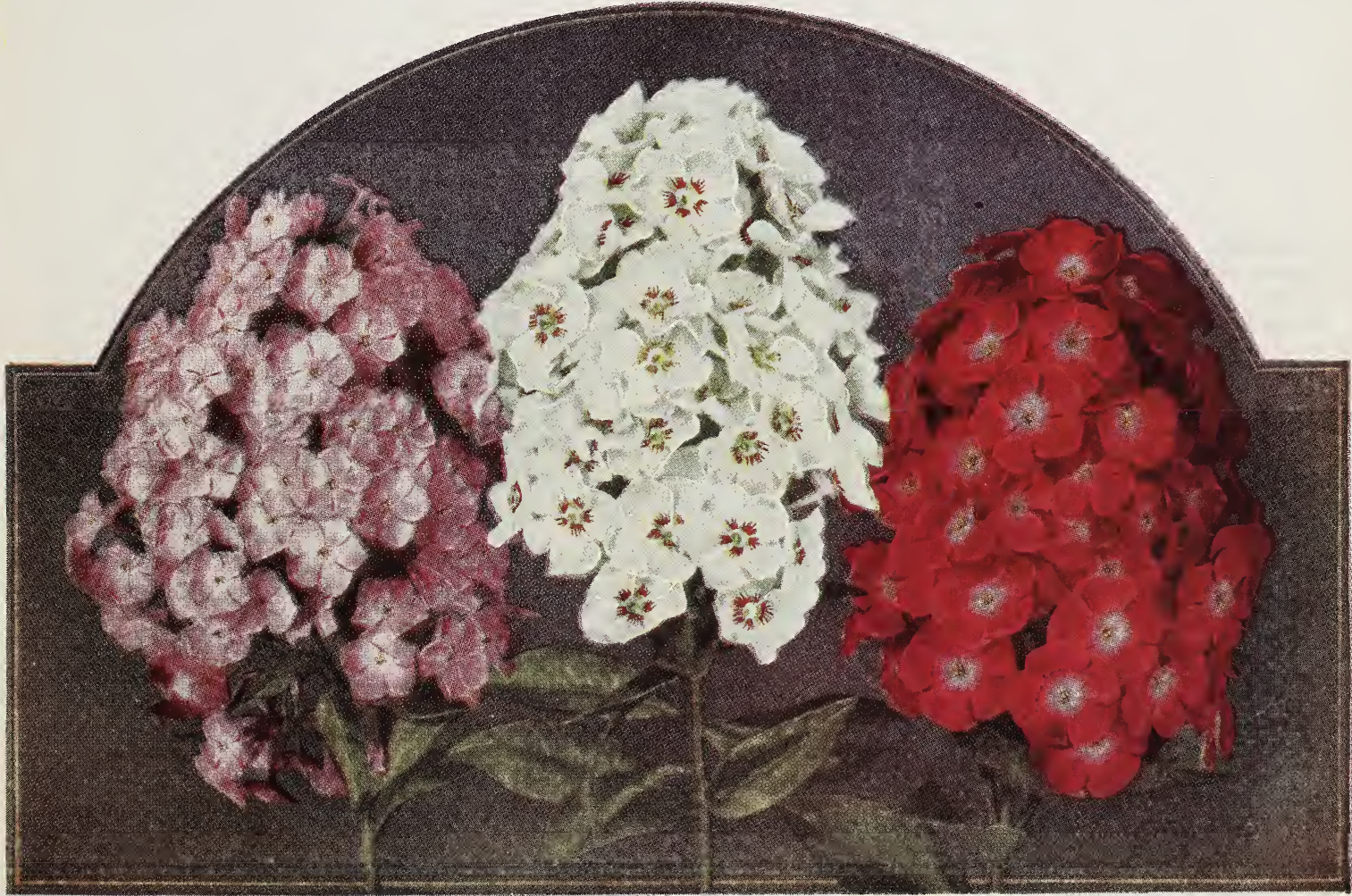



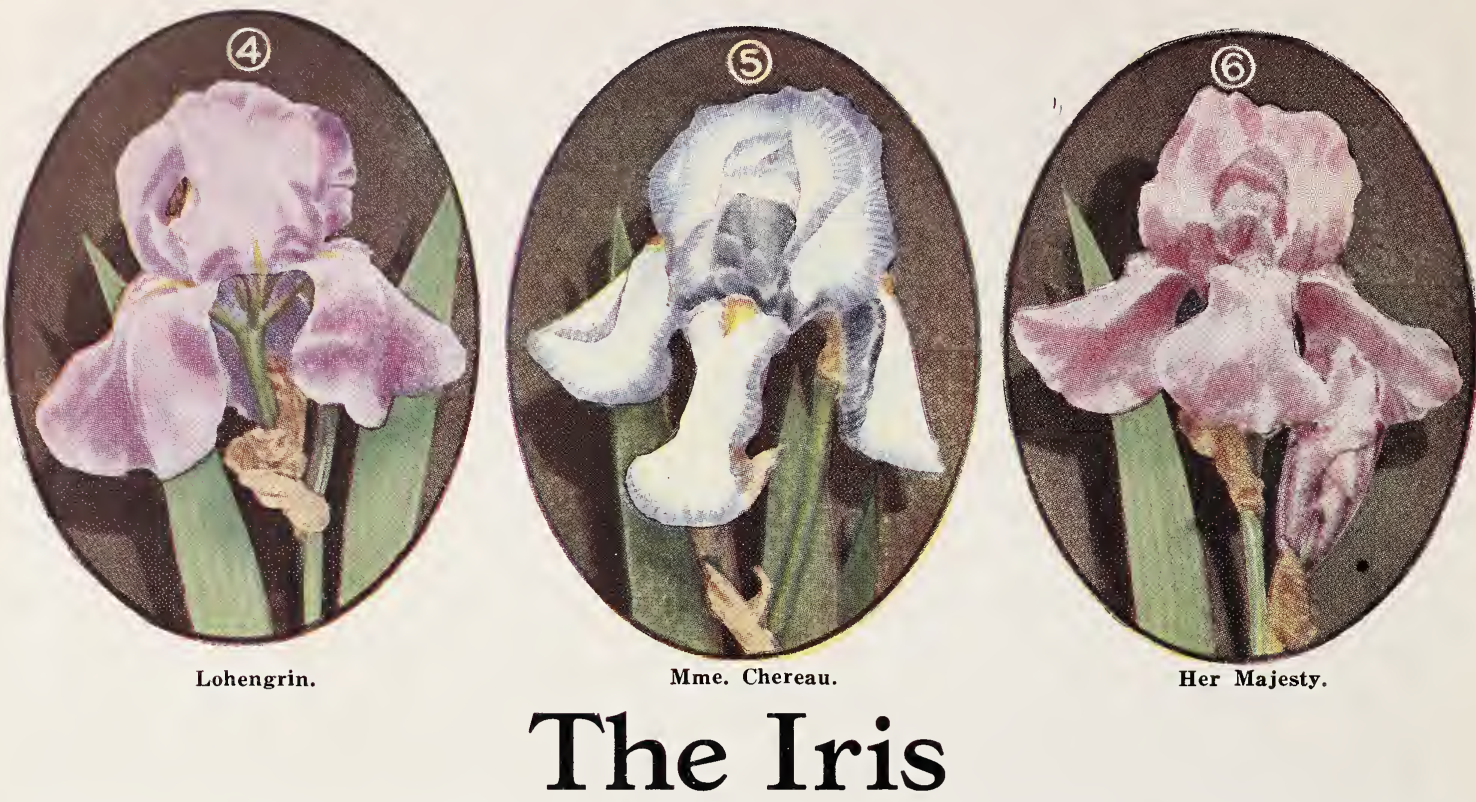

The Iris has justly been called the "Poor Man's Orchid." In curious shapes, in richness and variety of colorings it is in close rivalry with that exquisite aristocrat among flowers, and what makes it more popular and valuable is that it requires none of the professional care and coddling which the orchid must have.

Varieties can be selected which will grow in almost any kind of soil possessing a fair degree of fertility. Of course, the better the soil, the more satisfactory will be the results.

Fertilize sparingly with bone meal. Stable manure is injurious.

The Japanese Iris thrive much better in fairly heavy soil and a wet location. In planting barely cover to the crown with soil.

Our block was a gorgeous sight this year with one sheet of bloom nearly four feet high.

\section{IRIS - German}

Following Standard Sorts:

\begin{tabular}{|c|c|c|c|}
\hline & $\mathrm{Each}$ & cis & 106 \\
\hline $\begin{array}{cl}\text { Caprice. } & \text { Rosy claret } \\
\text { Celeste. Azure blue }\end{array}$ & & $\$ 1.20$ & $\$$ \\
\hline $\begin{array}{l}\text { Celeste. Azure blue } \\
\text { Florentina. Light blue }\end{array}$ & .20 & $\begin{array}{l}1.20 \\
1.20\end{array}$ & \\
\hline Fulda. Dark blue & .20 & 1.20 & \\
\hline eamy yellow & & & \\
\hline an. Creamy v & .2 & 1. & \\
\hline Her Majesty. Rose-pink & 2 & 1.20 & \\
\hline Honorabilis. Yellow .. & 2 & 1.20 & \\
\hline $\begin{array}{l}\text { Madame } \text { Chereau. White, } \\
\text { fringed blue ............ }\end{array}$ & 20 & 1.20 & 8. \\
\hline $\begin{array}{l}\text { Irs. H. Darwin. White, } \\
\text { crimson ............ }\end{array}$ & . 20 & & \\
\hline $\begin{array}{l}\text { Parasensis. Dee } \\
\text { Queen of May. }\end{array}$ & .20 & & \\
\hline $\begin{array}{l}\text { Queen of May. Rosy lilac ... } \\
\text { Walhalla. Lavender; falls wine }\end{array}$ & 20 & 1.20 & \\
\hline & 2 & & \\
\hline
\end{tabular}

New and Better Sorts. Large Flowering. (S) Standards; (F) Falls.

Rating

8.9 Alcazar. S soft blue; F deep brilliant purple. A grand, tall, large flowering Iris ........ \$0.50 $\$ 4.00$

Candelabre. Deep blue, flecked white $\dot{S} \ldots \ldots \ldots \ldots \ldots \ldots \ldots \ldots \ldots$.

7.9 King. $S$ clear yellow; $F$ rich maroon bordered yellow .....

9.6 Lent A. Williamson. $S$ bright lobelia-blue blended with yellow toward base. $F$ velvety pansy violet. Said to be the best Iris produced in America. Mammoth flowers ......... 2.00

$.40 \quad 3.20$
Rating

8.2 Lohengrin. Soft cattleya-rose. Very large $\ldots \ldots \ldots \ldots \ldots \ldots \ldots 0.25 \$ 2.00$

7.9 Loreley. S light yellow marked blue; $F$ ultramarine-blue, bordered cream .............. Midnight. Very dark blue. Fine.

$.25 \quad 2.00$

7.5 Mithras. S yellow; F wine-red

bordered yellow ...............
Pallida Albert Victor. Beautiful soft blue ............... .30

8.8 Pallida Dalmatica. Clear silvery lavender-blue. Very large ....

8.4 Rhein Nixe. S pure white; F deep violet-blue with white edge. Novelty

\section{IRIS - Japan}

We believe that our collection of this grand plant is as fine as can be found.

The following are all mammoth flowering sorts with that rich, golden throat.

Crimson Tuft. Crimson purple

falls. Center white and

gold. Single. Midseason ...\$0.30 $\$ 2.50 \quad \$ 20.00$

Double Blue Bell. Beautiful $\begin{array}{lllll}\text { deep blue. Very late } \ldots . . . & .30 & 2.50 & 20.00\end{array}$

Gold Bound. Creamy white, orange center. Double; early. $\quad \begin{array}{llll}30 & 2.50 & 20.00\end{array}$

Mahogany. Velvety mahoganyred. Double. Midseason. . $.30 \quad 2.50 \quad 20.00$ 


\section{JAPAN IRIS-Continued.}

Midnight. The deepest velvety Each 10 100 purple. Mammoth single flowers. Late. This one is gorgeous and different $\ldots . . \$ 0.50$

$\$ 4.00$

Ondine. White with blue veins, giving a pearly glistening appearance. Single. Midseason .................

Purple and Gold. Rich violetpurple. Midseason. Double.

Kamochi-guma. Dark purplish indigo. Midseason. A beautiful double .............

Tokio. The late white you are after. Single ............

$\begin{array}{ccc}.30 & 2.50 & 20.00 \\ .30 & 2.50 & 20.00 \\ .30 & 2.50 & 20.00 \\ .30 & 2.50 & 20.00\end{array}$

\section{Hemerocallis}

We are mentioning these two large flowering sorts of Lemon Lilies here because they bloom at the same time as Japan Iris and give a much needed yellow which blends with and brightens the Iris.

\section{Each Per 10}

Aurantiaca. Large brilliant orangeyellow flowers. Grows three to four feet $\ldots \ldots \ldots \ldots \ldots \ldots \ldots \ldots . \$ \ldots 0.30 \quad \$ 2.50$

Florham. Large, frilled, soft yellow flowers, swcetly scented. Tall ... .25

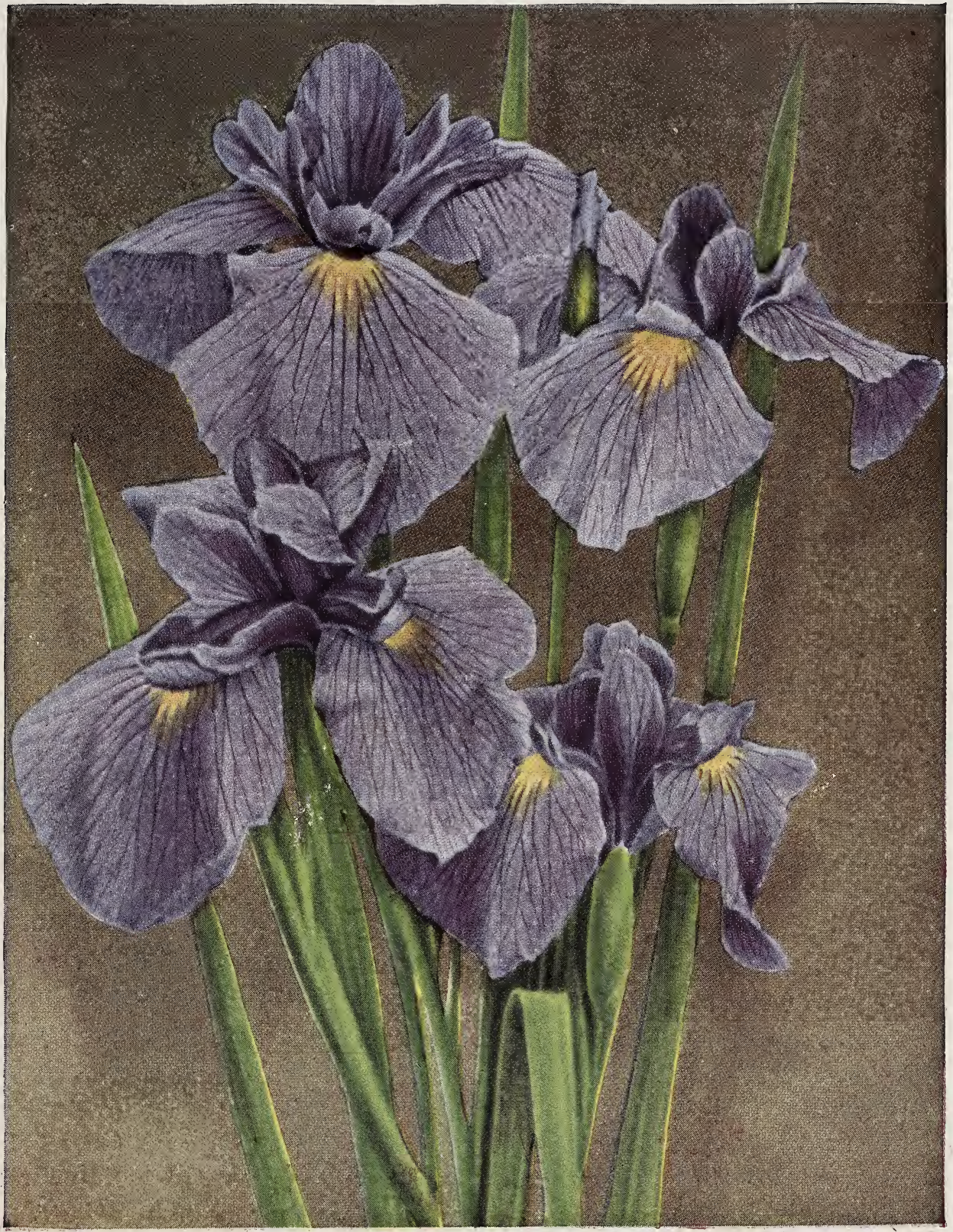




\section{Tulips}

Tulips should be planted six or eight inches apart and four or five inches deep, and given a light mulch. They can also be forced for Winter blooming by placing one or more bulbs in a pot and putting them away in a cool, dark place until rooted. The early varieties are best for forcing.

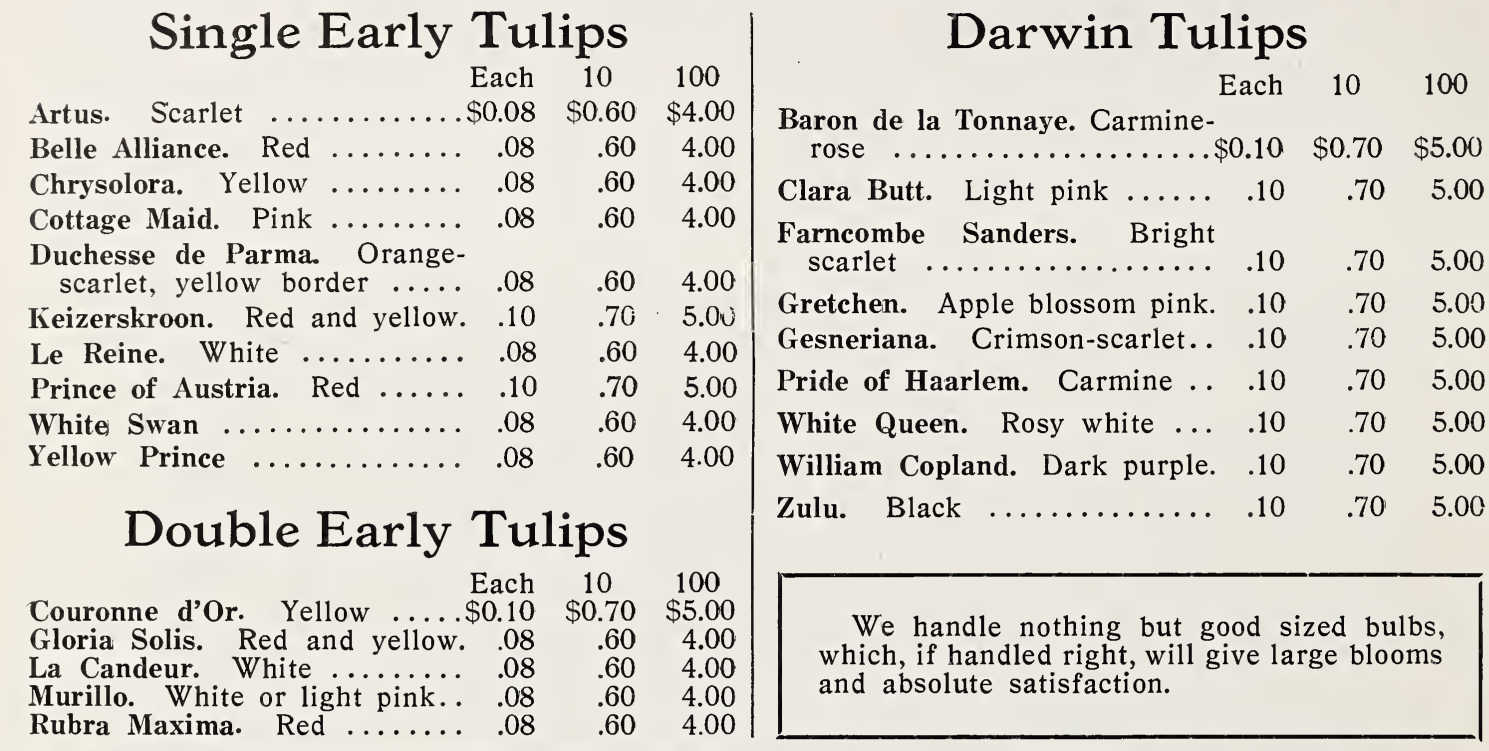

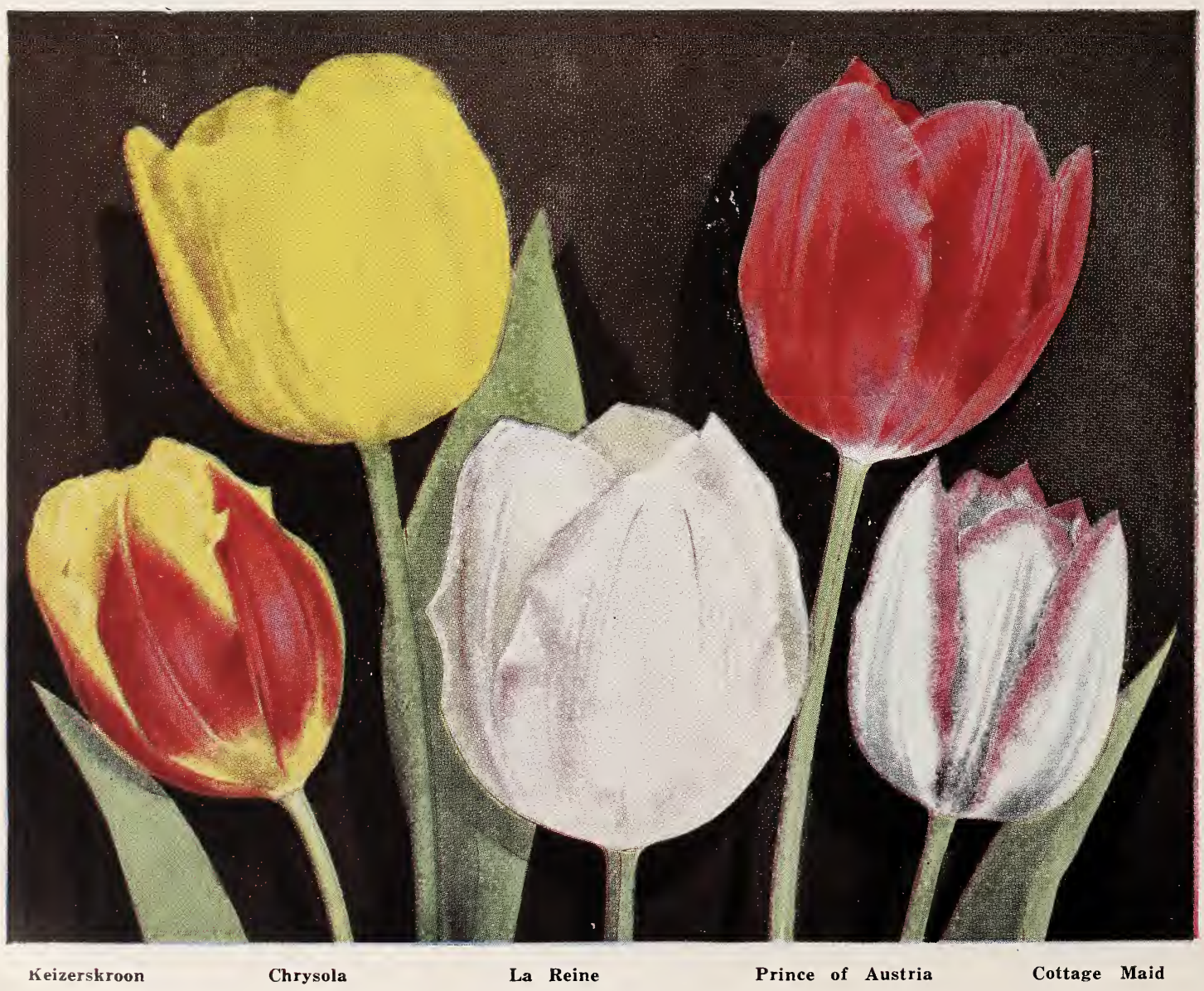




\section{Hyacinths}

Hyacinths are particularly desirable for growing in pots or glasses of water for Winter decoration. They can also be bedded the same as other Dutch bulbs.

\section{Single Hyacinths Named Colors}

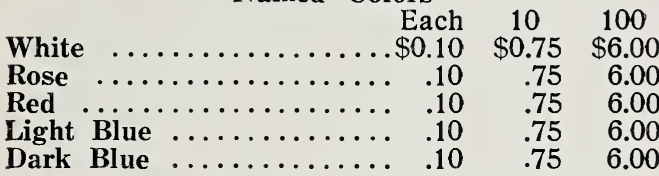

\section{Single Hyacinths \\ Named Varieties}

$\begin{array}{llll}\text { Each } & 10 & 100\end{array}$

Gertrude. Pink $\ldots \ldots \ldots . \$ 0.12 \quad \$ 1.00 \quad \$ 8.00$

Grand Maitre. Blue ..... $12 \quad 12 \quad 1.00 \quad 8.00$

King of the Blues ........ $.12 \quad 1.00 \quad 8.00$

Lady Derby. Pink ....... $.12 \quad 1.00 \quad 8.00$

L'Innocence. White $\ldots \ldots$.... $.12 \quad 1.00 \quad 8.00$

$\begin{array}{lllll}\text { Queen of the Pinks } \ldots \ldots & .12 & 1.00 & 8.00\end{array}$

Queen of the Blues $\ldots \ldots, \quad .12 \quad 1.00 \quad 8.00$

Yellow Hammer ........... $12 \quad 1.00 \quad 8.00$

\section{Double Hyacinths}

\section{Named Varieties}

$\begin{array}{rrr}\text { Each } & 10 & 100\end{array}$

La Grandesse. White $\ldots . \$ \$ 0.12 \quad \$ 1.00 \quad \$ 8.00$

Bouquet Tendre. Pink ...

President Roosevelt. Pink. $12 \quad 1.00 \quad 8.00$

\section{Narcissus}

For bedding, Narcissi should be planted the same as tulips, or they may be forced in pots for Winter cutting or decoration. Many varieties are particularly desirable for cutting on account of their long stems and graceful, sweet scented flowers.

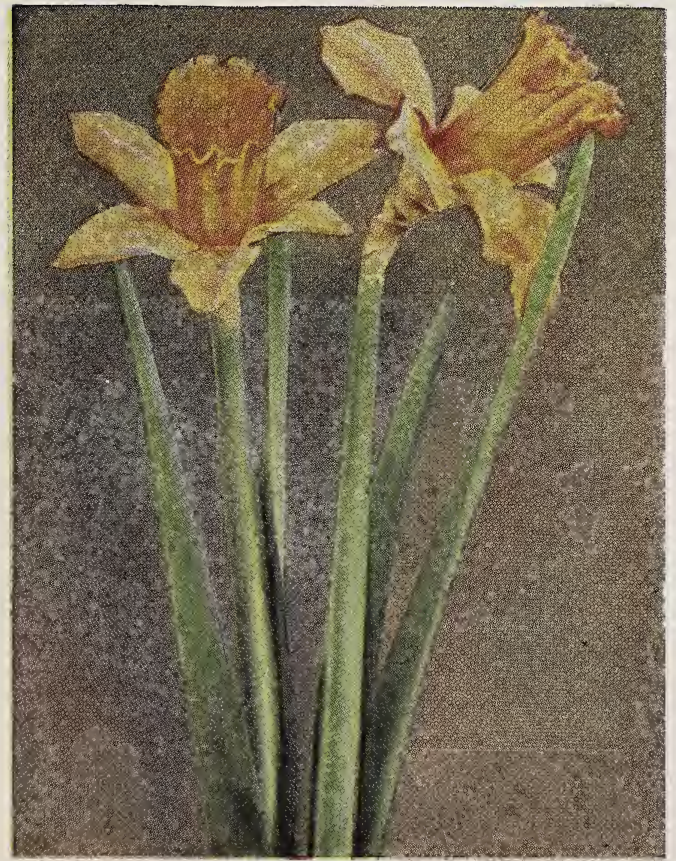

Golden Spur Narcissi.

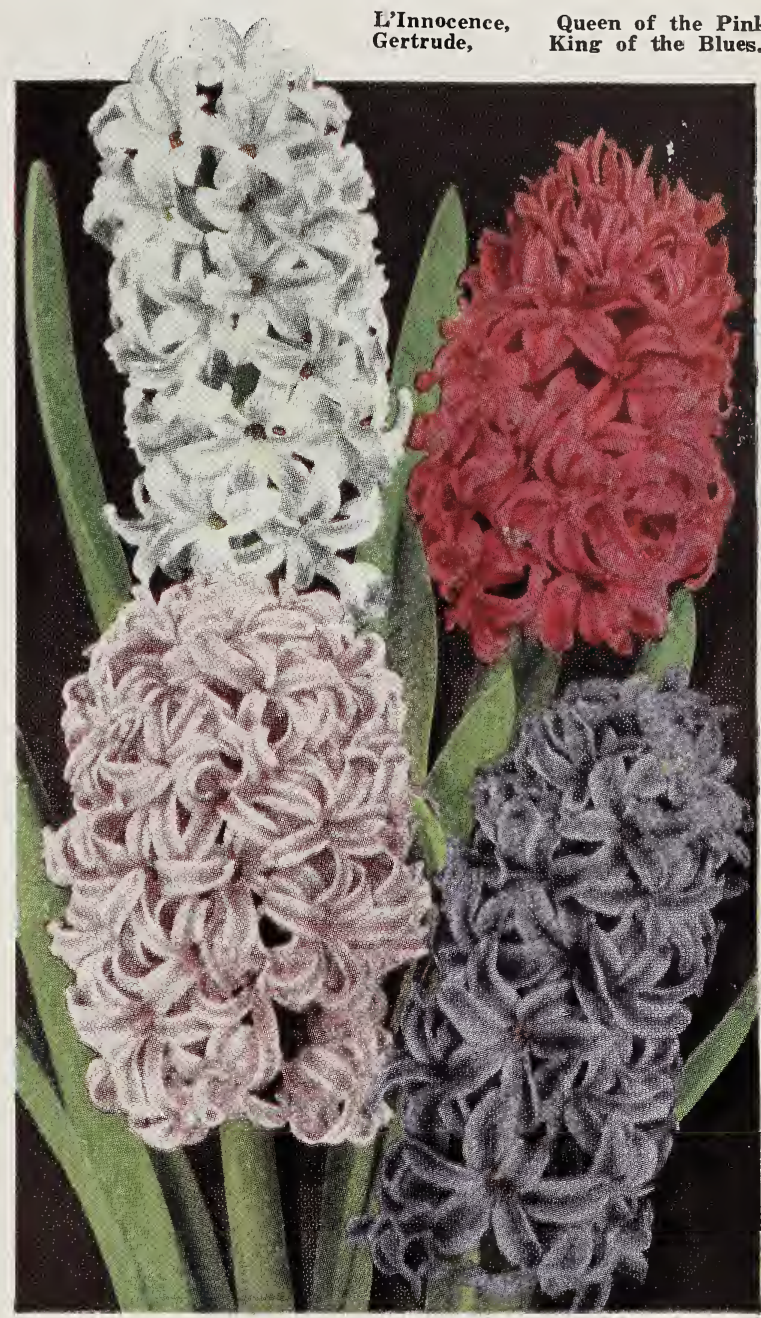

Single Narcissus

Emperor. Golden yellow trumpet. Each $10 \quad 100$ Primrose perianth .......... \$0.10 $\$ 0.75 \quad \$ 6.00$

Empress. White perianth. Yellow

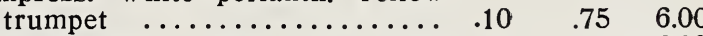
Golden Spur. Large rich yellow. $.10 \quad .75 \quad 6.00$

Poeticus. White perianth. Yellow cup, edged scarlet ....... $.08 \quad .50 \quad 4.00$

Poetaz Elvira. White with yellow eye .......................... $10 \quad .75 \quad 6.00$

Sir Watkin. Sulphur perianth, yellow cup ................ $.10 \quad .75 \quad 6.00$

Victoria. Creamy white perianth. Rich yellow trumpet ......... $10 \quad .75 \quad 6.00$

\section{Double Narcissus}

$\begin{array}{llll} & \text { Each } & 10 & 100 \\ \text { Alba Plena White } & \$ 0.08 & \$ 0.50 & \$ 4.00\end{array}$

Orange Phoenix. Orange and

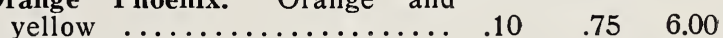
Von Sion. Pure yellow ...........

\section{Polyanthus Narcissus}

Paper-White Grandiflora. The Each 10 sweet scented, pure white sort used for forcing $\ldots . \ldots \ldots \ldots . \$ 0.10 \quad \$ 0.90 \quad \$ 6.00$ 

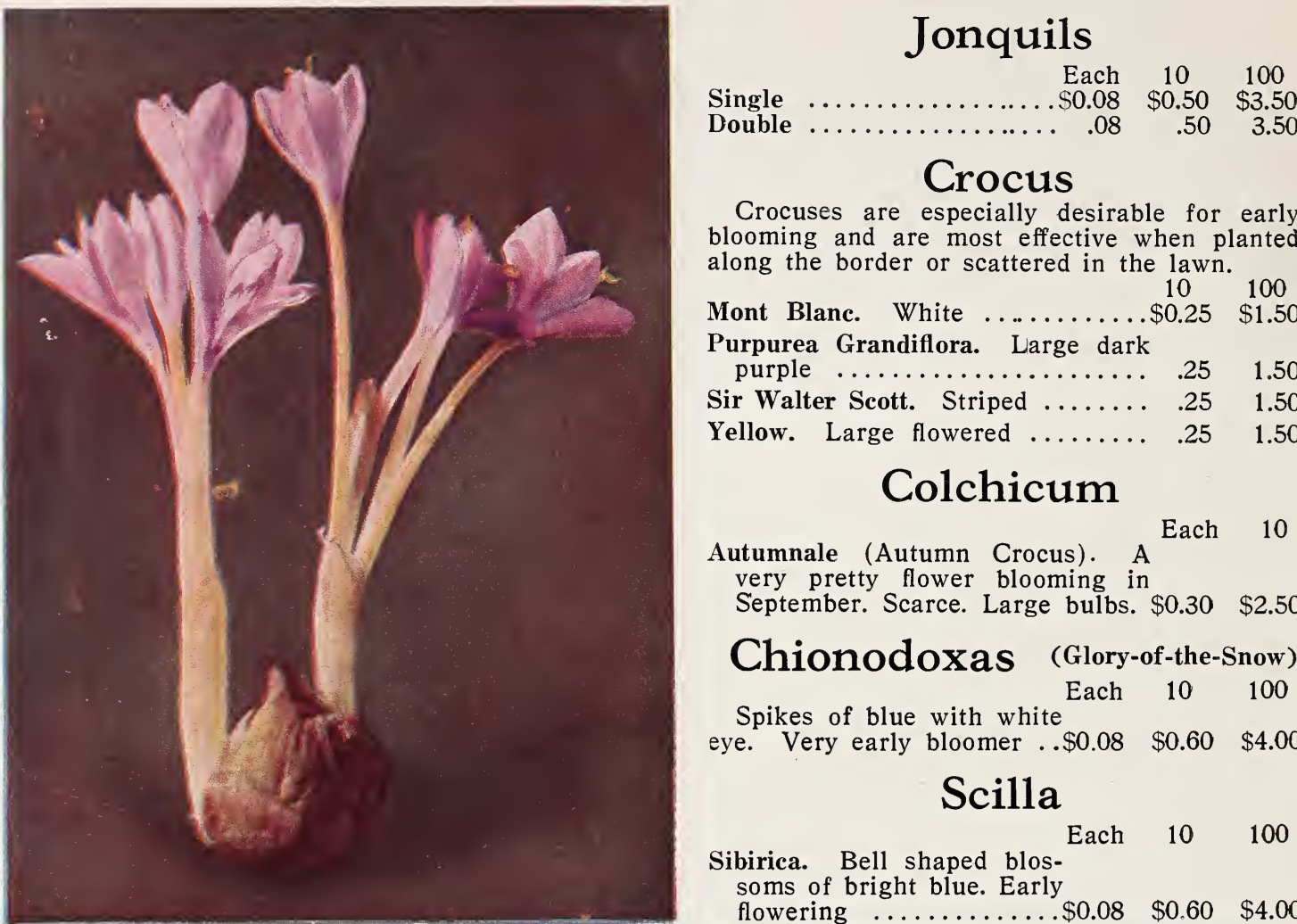

\section{Crocus}

Crocuses are especially desirable for early blooming and are most effective when planted along the border or scattered in the lawn.

Mont Blanc. White ..........\$0.25 $\quad \begin{array}{cc}100 \\ \$ 1.50\end{array}$

Purpurea Grandiflora. Large dark

purple $\ldots \ldots \ldots \ldots \ldots \ldots \ldots \ldots \ldots . .25 \quad 1.50$

Sir Walter Scott. Striped ....... . .25 1.50

Yellow. Large flowered ........ .25 1.50

\section{Colchicum}

Autumnale (Autumn Crocus). Each 10 very pretty flower blooming in September. Scarce. Large bulbs. $\$ 0.30 \$ 2.50$

Chionodoxas (Glory-of-the-Snow)

Spikes of blue with white Each $10 \quad 100$

eye. Very early bloomer $\ldots \$ 0.08 \quad \$ 0.60 \quad \$ 4.00$

\section{Scilla}

Sibirica. Bell shaped blos-

Each $\quad 10 \quad 100$

soms of bright blue. Early

flowering $\ldots \ldots \ldots \ldots \ldots . \$ 0.08 \$ \$ 0.60 \$ 4.00$

Colchicum.

\section{Snowdrops}

Delicate white bells. The Each 10 first llower to bloom in the Spring ...........\$0.08

\section{Lilies}

Auratum (Gold Banded Lily of Japan). Large, white flowers dotted crimson with a clear gold band down the center of each petal ................ $\$ 0.40$

Canadense (Meadow Lily). Grows six feet tall with drooping, bellshaped, red and yellow flowers ..

Candidum (Madonna Lily). Large, pure white. Fine for Winter flowering in pots ............

Regale. Our most satisfactory hardy Lily, recently introduced from China. Beautiful white flowers suffused with pink. Very sweetly scented. It has a long period of blooming from June through July.

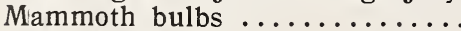

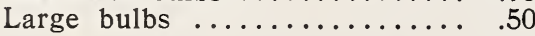

Speciosum album. Pure white ... Speciosum rubrum. White, spotted rosy red.
2.00

Each 10

6.50

4.00

3.50

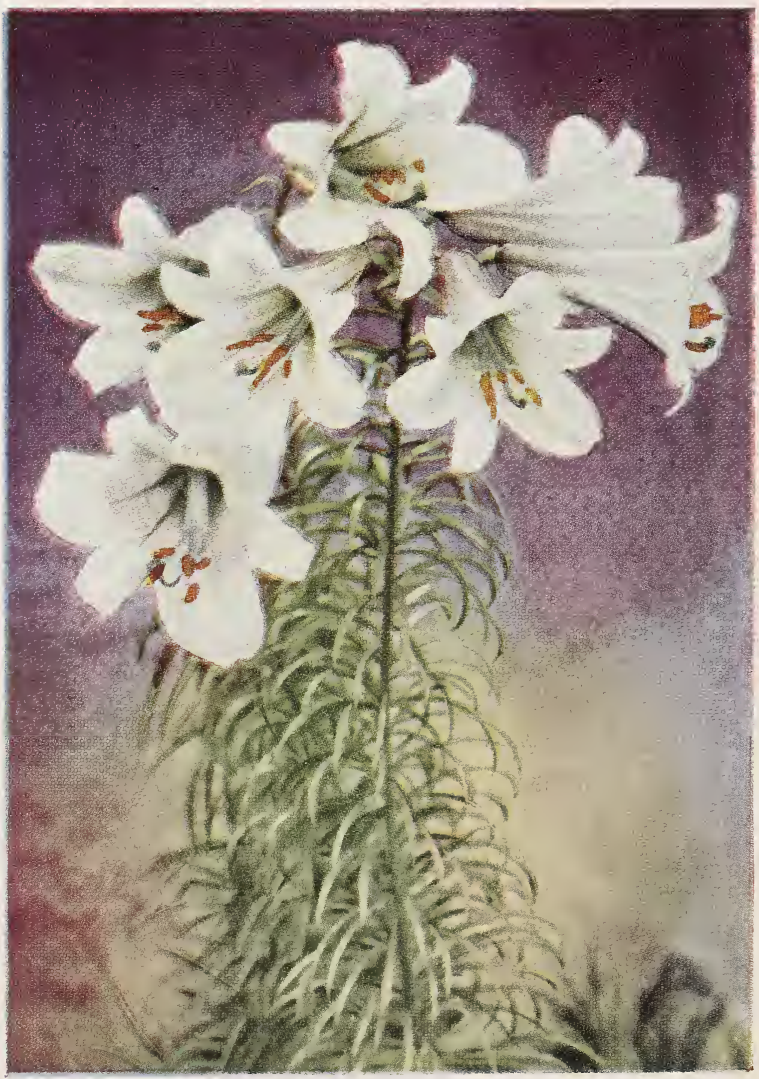

Regal Lilies. 


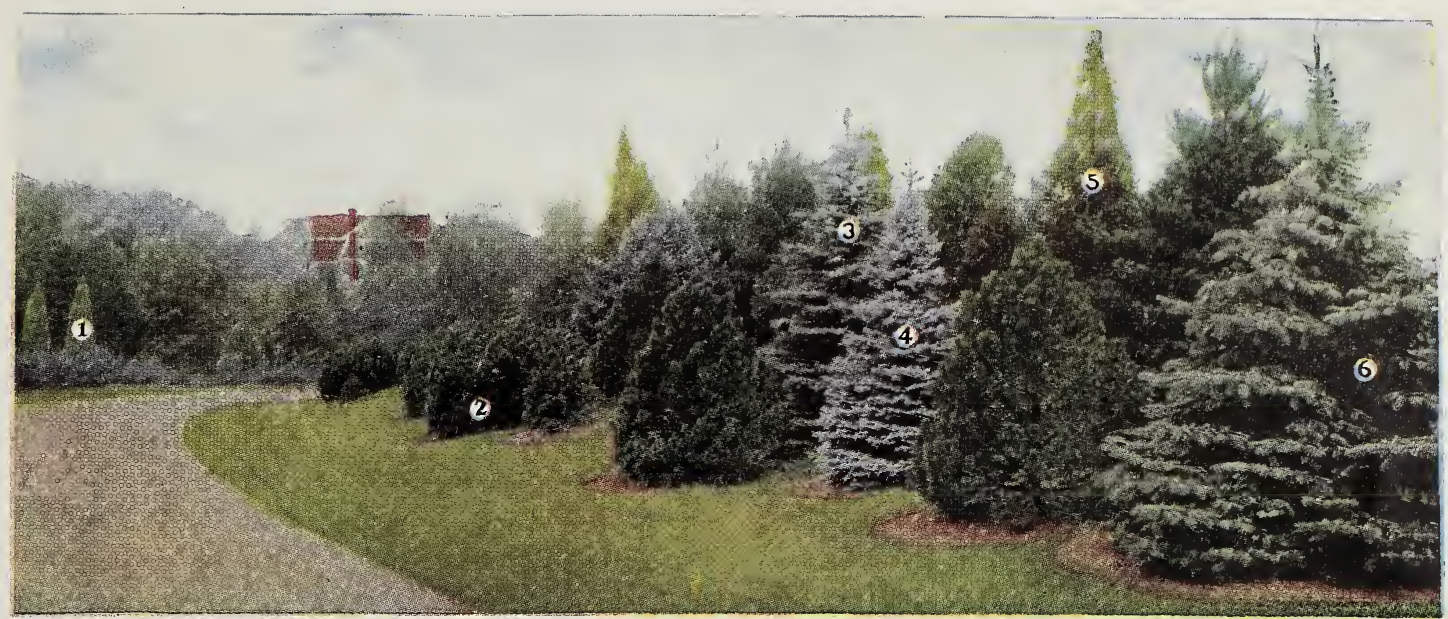

No. 1, Pyramidal Arbor-Vitae. No. 2, Mugho Pine. No. 3, Colorado Blue Spruce. No. 4, Koster's Blue Spruce. No. 5, American Arbor-Vita e. No. 6, Douglas Fir.

\section{Evergreens}

Our complete Descriptive Catalog describes a large variety of evergreens which can be best transplanted in the latter part of August and during September.

It also lists "EVERYTHING THAT IS GOOD AND HARDY" in nursery stock for later shipmentFRUITS

SHRUBS

SHADE

PERENNIALS

ROSES

\section{Terms and Responsibility}

\section{Prices}

We supply ten plants of a variety at the ten rate; fifty plants of a variety at the one hundred rate.

\section{Shipping}

F. O. B. Painesville, packing and boxing free. With small orders, which can be sent by parcel post, kindly add about as follows for postage:

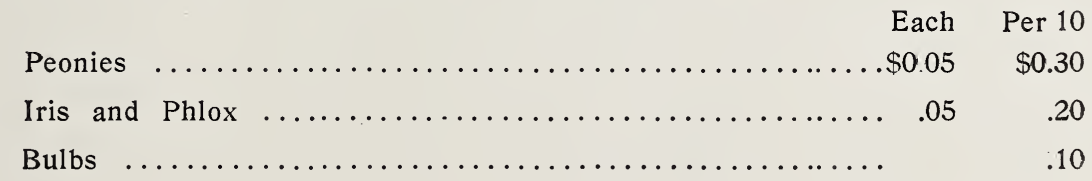

\section{Responsibility}

We exercise the greatest care to have nursery products true to name and we will gladly return the purchase price for all stock that proves not true. 


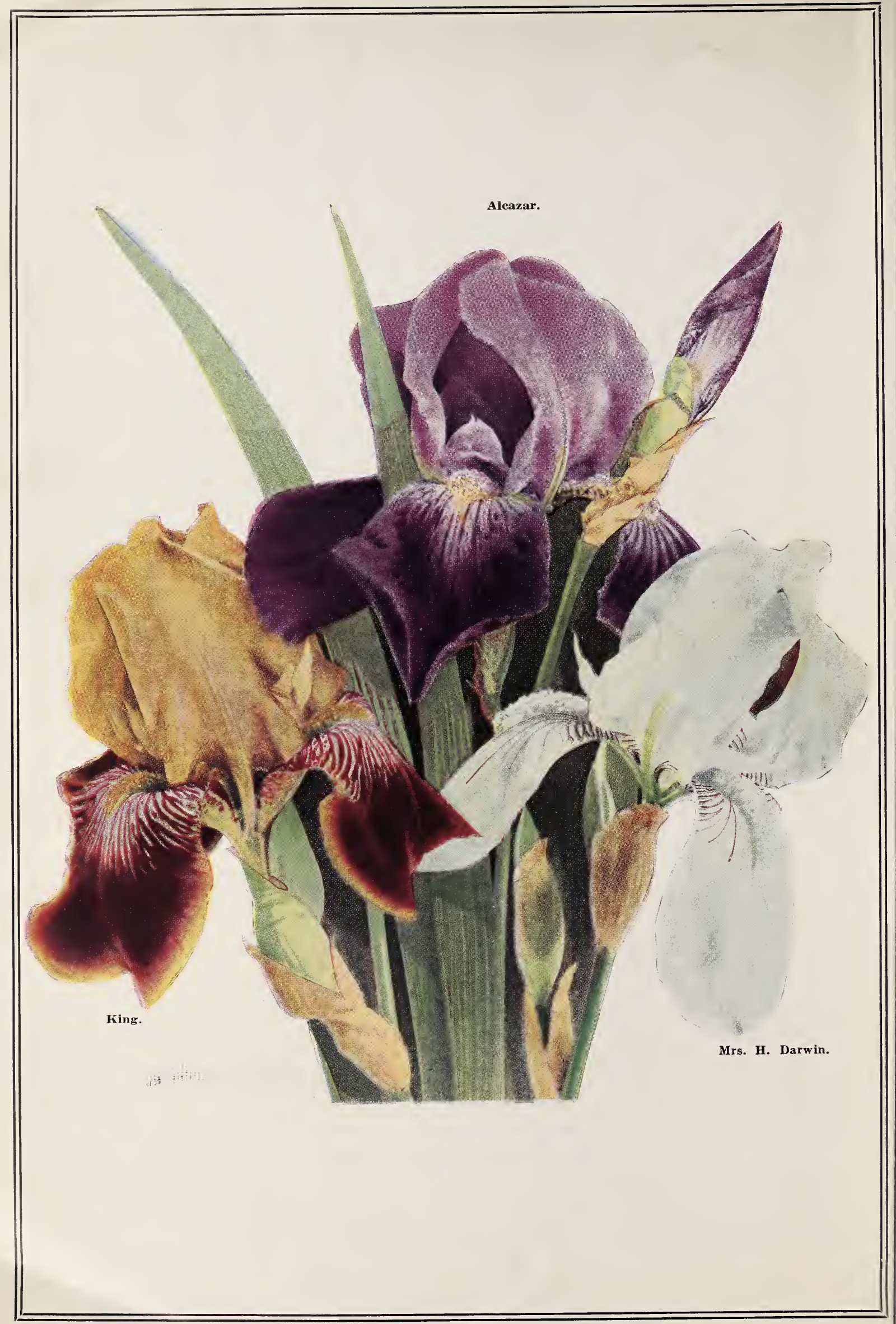

